\title{
The Effectiveness of Self-Tapping to Pain of Dysmenorrhoea
}

\author{
$1^{\text {st }}$ Siti Haniyah \\ Nursing Program \\ Harapan Bangsa University \\ Central Java, Indonesia \\ haniwiyana56@gmail.com
}

\author{
$2^{\text {nd }}$ Prasanti Adriani \\ Midwifery Program \\ Harapan Bangsa University \\ Central Java, Indonesia \\ pra.adriani@gmail.com
}

\begin{abstract}
Pain of Dysmenorrhea is a physiological condition that will generally be experienced by women who are menstruating. Pain is a manifestation of uterine muscle contraction.Self-Tapping is one of Nonpharmacologic therapy that aims to reduce physical pain and fatigue. The purpose of this research is to find out Self-Tapping effect toward the decrease dysmenorrhea pain level of Nursing Students in Harapan Bangsa University. The method of this research used quasi experimental design with non-equivalent control group research design. The respondent were 48 students consists of 24 control group and 24 treatment group. To know the decrease of pain scale In experiment group then using Paired T test and to know the effectifness of Self Tapping with dysmenorrhea pain is used of Independent $T$ Test.The result of this research indicated that there are differences in the level of dysmenorrhea pain before and after self tapping in treatment group with $p$ value is 0,000 and Self Tapping effectifness in decreasing dysmenorrhea pain level with $P p$ value is 0,000. For researcher furthermore, so that experiment with increase frequency and repair monitoring method, enough moment performed Self Tapping.
\end{abstract}

Keyword: dysmenorrhea, pain, self-tapping

\section{INTRODUCTION}

Occurs dysmenorrhea, the woman will feel pain and the impact of the pain will cause the mobilization to be limited, Activity of Daily Living (ADL) is interrupted because of the increased intensity of pain when moving. The incidence of dysmenorhea in adolescents in Asia is 74, 5\%. Hispanic female prevalence of dysmenorhea was $85 \%$, while the incidence in Indonesia was $55 \%$. Looking at these data can be interpreted that almost all women have experienced dysmenorhea (1).

Efforts to manage pain in dysmenorrhea are pharmacological and non-pharmacological. Pharmacologically painful control is effective for moderate and severe pain. The provision of pharmacology does not aim to improve the client's own ability to control pain, so a combination of pharmacology is needed to control pain with nonpharmacology so that the sensation of pain can be reduced and the recovery period is not elongated (2) Non-pharmacological treatment that can reduce pain, can also start from the simple, such as compressing with hot temperatures to hypnotic ways. One of the non-pharmacological treatments that can reduce pain is selft tapping therapy. Self tapping is tapping touch that is done independently. Self tapping can apply basic touch techniques to yourself and does not require a lot of money. Touch Tapping is a holistic treatment technique using touch and rhythm. Although it is made easy to learn and simple to do, Touch Tapping was developed through the integration of therapeutic elements that have proven effective through clinical and research use

HarapanBangsa University has also been used as a place of research on decreasing dysmenorhea pain such as drinking sour turmeric, Ar Rahman murotal therapy, yoga, progressive muscle relaxation \& aromatherapy, deep back massage, hypnoanalgesia and mozart classical music therapy, but for complementary self tapping therapy has never do.

\section{METHODOLOGY}

The location of this study at HarapanBangsaUniversity. The independent variables in this study are: Self Tapping is a holistic treatment technique using touch and Rhythm. Tap gently with the ball of the right and left fingers alternately. Self Tapping actions are also performed 3 times a day for 3 days or when pain is felt. How to measure using the observation sheet in the form of a self-tapping exercise checklist sheet Measuring results are categorized into Self-tapping and not self-tapping, with a nominal measuring scale.

Dependent variable: Dysmenorrhea pain is a parameter used to assess unpleasant sensory and emotional experiences related to contractions obtained during menstruation at HarapanBangsa University. How to measure using the Numeric Rating Scale Pain Scale was measured 3 times, with the results of the assessment in the form of the average results of the measurement and the measuring scale is the ratio.

The design in this study was quasi pre post test with control group. Based on the research design mentioned above, the research design is as follows: 


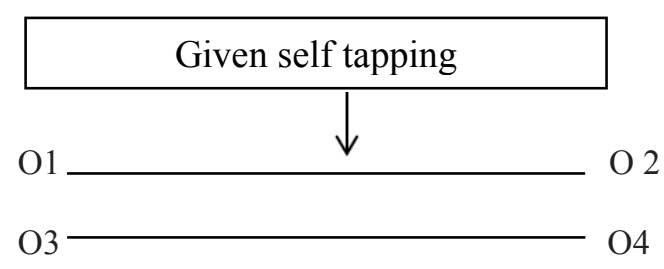

Figure 3.1: Chart of Research Design Information:

O1: Pain Treatment Group (KP1) Scale before being given a self tapping technique;

O2: KP 1 Pain Scale after being given a self tapping technique

O3: Control Group (KK1) Scale of pre test pain

O4: Control Group (KK1) Post-test pain scale

The samples collected in this study were determined by the sample formula in the experimental study or clinical trial

So the sample used in this study is 24 students with primary dysmenorhea pain as many as 24 students in the self tapping group and 24 and the control group as many as 24 female students. So the sample I took was 48 students

The sampling technique used in this study was purposive sampling, by determining the sample based on the wishes of the researcher based on the criteria established during the study.

The data collection technique used in this study was the assessment of the scale of pain in dysmenorrhea before and after being given the treatment of self tapping using the Numeric Rating Scale pain scale.

At the time of data collection researchers will only intervene on the respondent, the respondents studied were given not to use anti-pain medication during the study, while measuring the Numeric Rating Scale both before and after treatment will be carried out by the research assistants. The research assistants consisted of students from Harapan Bangsa University. The measurement of the pain scale is carried out by the research assistants aimed at avoiding the subjectivity of the researcher. Therefore, the perception is done with the research assistants including SOP self-tapping and how to measure the pain scale and work procedures of the research that will be carried out.

Data analysis methods used in this study include univariate analysis and bivariate analysis. Univariate analysis for

before the research is done, get a description / descriptive of each research variable. Univariate analysis includes mean, mode, median, minimum and maximum values, standard deviation, variance and distribution and proportion of patient characteristics as well as pre test and post test.

The bivariate analysis used in this study is as follows: To find out the difference in pain scale in the control and intervention groups, if the data is normally distributed then use the

Paired $\mathrm{T}$ test. To find out the difference in pain scale between the control groups and the intervention group if the data distribution was normal, use the Independent $\mathrm{T}$ test.

\section{FINDINGS AND DISCUSSION}

This study aims to determine the effect of self tapping on dismenorrheal pain in 48 second semester nursing students at HarapanBangsa University as many as 48 students with a division of 24 students in the Self Tapping Characteristics of Respondents. In general, the characteristics of respondents described in this study are age and information about Self Tapping Table 1 Characteristics of respondents

\begin{tabular}{|c|c|c|c|c|c|}
\hline \multicolumn{2}{|c|}{ Characteristics } & \multicolumn{2}{c|}{ Self Tapping } & \multicolumn{2}{c|}{ Control } \\
\cline { 3 - 6 } \multicolumn{2}{|c|}{} & $\mathrm{f}$ & $\%$ & $\mathrm{f}$ & $\%$ \\
\hline \multirow{4}{*}{ Age } & 17 years & 1 & 4.2 & 0 & 0 \\
\cline { 2 - 6 } & 18 years & 12 & 50 & 7 & 29.2 \\
\cline { 2 - 6 } & 19 years & 10 & 41.6 & 13 & 54.1 \\
\cline { 2 - 6 } & 20 years & 1 & 4.2 & 4 & 16.7 \\
\cline { 2 - 6 } & Total & 24 & 100 & 24 & 100 \\
\hline $\begin{array}{c}\text { Info } \\
\text { Self } \\
\text { Tappin } \\
g\end{array}$ & Ever & 0 & 0 & 0 & 0 \\
\cline { 2 - 6 } & Never & 24 & 100 & 24 & 100 \\
\cline { 2 - 6 } & Total & 24 & 100 & 24 & 100 \\
\hline
\end{tabular}

Based on table 1 the variation in age of the respondents ranged from 17-20 years. The lowest age is 17 years as many as 2 people while the most age is the age of 19 as many as 23 people Meanwhile, all respondents have not received information on Self Tapping (100\%).

Level of Dysmenorrhea Pain Before and after being given Self Tapping

Tabel 2. Level of Dysmenorrhea Pain Before and after being given Self Tapping

\begin{tabular}{|c|c|c|c|}
\hline Kategori & $\begin{array}{c}\text { Mea } \\
\text { n }\end{array}$ & $\begin{array}{c}\text { Std. } \\
\text { Deviasi }\end{array}$ & $\begin{array}{c}\text { Min- } \\
\text { max }\end{array}$ \\
\hline Pre Test & 5.42 & 1.349 & $4-8$ \\
\hline Post Test & 2.46 & 1.044 & $1-5$ \\
\hline
\end{tabular}

based on table 2 it can be seen that the average value of dysmenorrhoea pain before Self Tapping is 5.42 with the lowest pain value is 4 and the highest is 8 . While the average value of pain in dysmenorrhea pain after being given Self Tapping is 2.46 with a value the lowest pain is 1 and the highest is 5 .

2. Differences in Pain in Dysmenorrhea After Given Self Tapping in the treatment and control groups

Table 3 Differences in Dysmenorrhea Pain Before and After Given Self Tapping in the treatment and control groups

\begin{tabular}{|c|c|c|}
\hline Kelompok & Mean Rank & P Value \\
\hline Self Tapping & 2.46 & \multirow{2}{*}{0.000} \\
\cline { 1 - 2 } Kontrol & 4.67 & \\
\hline
\end{tabular}


Based on Table 3, it was found that the mean post-test rank of the kntrol group was greater than Self Tapping by 4.67 meaning that the pain that was not treated was greater than the one treated by Self Tapping and $\mathrm{P}$ Value of 0.000 .

1. Pain levels of dysmenorhea before and after self tapping

The results showed that the level of pain of female students before the Self Tapping action that the level of pain of the respondents before being given Self Tapping of Dismenorrhoea pain was 5.42 While the mean value of pain in dysmenorrhea pain after being given Self Tapping was 2.46 .

In theory, pain is an unpleasant sensory and emotional experience and is associated with tissue damage, both actual and potential damage. Its nature is very subjective because the feeling of

pain is different in each person in terms of scale or level and only that person can explain or evaluate the pain experienced (3)

Generally, pain dysmenorrhea arises from the endometrium producing prostaglandin F2 which causes the movement of smooth muscles. If the excessive amount of prostaglandin is released into the bloodstream, it will cause pain during menstruation (4)

In line with the research conducted by Sirait (2018), 8 people $(32.0 \%)$ with moderate pain scale and moderate pain scale dysmenorhea sufferers were 17 people $(68.0 \%)$, and there were no patients with severe dysmenorhea. . The research conducted by the researcher, began by conducting interviews with respondents about the experience of perceived dysmenorhea pain, then the researcher gave a procedure sheet to implement the self tapping technique and demonstrate it and provide a coherent explanation. Then, the researchers asked respondents to measure the scale of pain dysmenorhea felt by respondents before (pretest) self tapping technique was done by using the Numeric Rating Scale (NRS).

According to the theory, that self tapping therapy is useful for reducing pain. Because being comfortable is fundamental, so choose rhythms and locations for comfortable tapping (5)

According to a study conducted by Sirait (2018), the number of respondent pain scales after self tapping was a mild pain scale of 25 people $(100 \%)$ and moderate pain scale was absent. Respondents with moderate pain scale were respondents with severe pain before self tapping. After self tapping techniques, respondents stated a decrease in the level of pain felt. The lower abdomen that previously cramps becomes more relaxed.

2. Differences in the level of pain in dysmenorhea before and after Self Tapping at Nursing Students at HarapanBangsa University, Purwokerto.

Based on table 3 the results show that the mean rank post test is 2.46 and $\mathrm{P}$ Value is 0,000
The purpose of self tapping is to eliminate physical tension, provide a new feeling of comfort and energy, reduce physical pain and fatigue, reduce symptoms of physical stress, activate the parasympathetic nervous system and increase serotonin (The Association of Tapping Touch, 2010). The Self Tapping mechanism so that pain can go down because according to a recent study conducted at Toho University Japan regarding the effect of tapping therapy on serotonin hormones showed that the results of tapping therapy can increase serotonin hormone. Serotonergic (5-HT) neurons are known to play a role in eliminating anxiety, pain, tension and depressive symptoms in humans(6)

Self Tapping or Tapping Touch is a therapy that involves rhythmic behavior, which is by rhythmically touching using the fingers of the right and left hands alternately. This rhythmic movement causes an increase in serotonin secretion.

The effect of self tapping on decreasing dysmenorhea pain levels, where pain level measurements are carried out before and after self-tapping. Based on the results of the Wilcoxon test, there was a significant effect of self tapping on a decrease in the level of pain in dysmenorhea.

The results of this study are supported by the results of a study conducted by Arita at the Toho University Medical Department, that there was a significant increase in serotonin levels between before and after therapy with self tapping. In addition, to assess psychological effects measurements were made with the parameters of the Profile of Mood States (POMS) and Visual Analog Scale (VAS). The results showed that there was a reduction in anxiety, fatigue, confusion, stress, and pain (The Association of Tapping Touch, 2010).

According to research conducted by(7), shows that there are significant differences for pain scores before and after self tapping with a value of $p<0.01$.

In this study, because the value of $p$ value 0,000 is smaller than $<0,05$, it can be concluded that "Ha is accepted", meaning that there are differences before and after self-tapping. So it can be concluded that there is an effect of self tapping on decreasing the level of primary dysmenorhea pain in nursing students at HarapanBangsa University.

3. Effectiveness of Self Tapping on pain dysmenorhea in Nursing Student at HarapanBangsa University Purwokerto.

The results of statistical tests showed that there were significant differences in the decrease in pain level before intervention between the treatment group and the control group with $\mathrm{p}$ value 0,000 , the treatment group produced mean rank 2.43 and the control group produced mean rank 4.67 So it can be concluded that there are differences significant level of pain dysmenorhea before intervention between the treatment group and the control group, where in the treatment group the pain level was higher than the control group. According to the theory, the steps of 
held relaxation and Self Tapping when dysmenorrhea pain lasts.

The next researcher can develop this study by comparing Finger Handheld Relaxation with other non-pharmacological pain management methods such as Benson, autogenic etc. to overcome desminore pain collarbone and chest, tapping the abdomen, tapping the lower back and placing the hands in the lower abdomen (5).

Research conducted by(7), to compare pain reduction in the intervention group and the control group, showed that self tapping interventions were more effective in reducing the level of primary dysmenorrhea pain in PSIKFK UGM students with a $\mathrm{p}$ value $<0.01$.

So from this study it can be concluded that there is a significant difference between the treatment group and the control group in decreasing the level of pain in dysmenorhea, where the treatment group was more effective in reducing pain than in the control group

\section{CONCLUSIONS}

The Mean Value of Dysmenorrhea Pain in Nursing Students in Semester II before was 5.42 and decreased after the Finger Tapping Technique was carried out to 2.46 with $P$ value 0.00

Self Tapping is effective in reducing dysmenorrhea pain in Nursing Students in Semester II with a value of P Value 0.00

\section{RECOMMENDATION}

HarapanBangsa University is expected to apply finger handheld relaxation therapy and Self Tapping as a permanent procedure for complementary therapy to treat dysmenorrhea pain.

Second semester students at HarapanBangsa University are expected to be able to practice finger-

\section{REFERENCES}

1. Setyowati H. Akupresur untuk Kesehatan Wanita Berbasis Hasil Penelitian. Press U, editor. Magelang; 2018.

2. Bobak, Lowderni J. Buku Ajar Keperawatan Maternitas. EGC, editor. EGC; 2012.

3. Ramadhani, A.N D. Buku Saku Praktik Klinik Keperawatan Edisi Revisi. Salemba Medika, editor. Jakarta; 2017.

4. Laila NM. Buku Pintar Menstruasi. Biru B, editor. Yogyakarta; 2011.

5. Nakagawa I. Tapping Touch- Perawatan Holistik untuk Pikiran, Tubuh \& Planet. In: Tokishobo Books, editor. Jepang; 2010.

6. Madjid A. Pendidikan Karakter Perspektif Islam,. Rosda Karya, editor. Bandung; 2011.

7. Lismidiati W, Santi NF, Akbar HW. Pengaruh Self Tapping terhadap Penurunan Level Dysmenorhea pada Mahasiswi Program Studi Ilmu Keperawatan. J Keperawatan Padjadjaran. 2017;5(1):57-64. 